\title{
Rapid Ecological and Environmental Assessment of Osun Sacred Forest Grove, Southwestern Nigeria
}

\author{
Adisa Ogunfolakan, Chinyere Nwokeocha, Ayodeji Olayemi, Moshood Olayiwola, \\ Adebola Bamigboye, Adenike Olayungbo, Joan Ogiogwa, Oyeseyi Oyelade, \\ Olanipekun Oyebanjo
}

Natural History Museum, Obafemi Awolowo University, Ile Ife, Nigeria

Email: bogunfol@oauife.edu.ng

Received 18 May 2016; accepted 8 July 2016; published 11 July 2016

Copyright (C) 2016 by authors and Scientific Research Publishing Inc. This work is licensed under the Creative Commons Attribution International License (CC BY). http://creativecommons.org/licenses/by/4.0/

\begin{abstract}
Osun Sacred Forest Grove is a unique landscape that combines important environmental, biological and cultural features. We conducted a multifaceted rapid assessment to evaluate the conservation status of the grove eleven years after it was designated a World Heritage Site. We recorded a rich diversity, consisting of 2 rock types, 3 minerals, 88 plant species, 108 insect families and 4 mammal species. Our survey also enabled us document up to 40 cultural artifacts. However, the plants, small mammals and insects collected, in their role as indicator taxa, demonstrate that biodiversity decreases extending outward from the core area of the grove into the buffer and outside zones. In addition, the detection of heterotrophic bacteria and fungi from microbiological analyses in water samples of the Osun River which runs through the grove raises health concerns. Our findings lead us to recommend that efforts be stepped up to deter encroachment of the buffer and outside zones into the core area of the grove. Furthermore, careful repair of deteriorating cultural artifacts should be undertaken regularly, with the actions of visitors monitored adequately to prevent depletion of biodiversity and pollution of the environment.
\end{abstract}

\section{Keywords}

Osun, Sacred Forest, Rapid Assessment

\section{Introduction}

From ancient times sacred groves, invoking religious and ethnic ideals have represented an alternate but effec-

How to cite this paper: Ogunfolakan, A., Nwokeocha, C., Olayemi, A., Olayiwola, M., Bamigboye, A., Olayungbo, A., Ogiogwa, J., Oyelade, O., \& Oyebanjo, O. (2016). Rapid Ecological and Environmental Assessment of Osun Sacred Forest Grove, Southwestern Nigeria. Open Journal of Forestry, 6, 243-258. http://dx.doi.org/10.4236/ojf.2016.64020 
tive means of conserving biodiversity. In modern times, these traditional efforts at conservation are becoming increasingly reinforced by legislative and governmental frameworks. These groves are usually rich patches of undisturbed forest, serving as a natural habitat for endemic, rare, primitive and economically valuable organisms (Lyngwi \& Joshi, 2015). Results of a comparative study have also shown that sacred groves shelter high diversity of medicinal plants and have more vigorous regeneration of trees than formal forest reserves (Baraiah et al., 2003). Therefore inventories are desirable to assess the diversity present in these groves.

Nevertheless, most surveys of forest biodiversity in south-western Nigeria have targeted singular taxa (e.g., Ogunjemite \& Olaniyi, 2012; for Chimpanzees in Oluwa Forest Reserve) or a particular segment of the biota (Aigbe \& Omokhua, 2015; on trees in Oban Forest Reserve). Biodiversity is interactive, with varied taxa influencing and depending on each other. Insects pollinate plants and serve as prey to rodents and birds, which in turn help to disperse seeds. In addition, non-biological components of the environment (physical and even cultural aspects) affect the well-being of biota. For instance, the integrity and freshness of streams and rivers (i.e., the physical environment) affect their capacity to serve as a substrate and habitat for aquatic organisms, while taboos within certain ethnic groups (the cultural environment) have actually played a positive role in preserving certain forest species such as primates in Indonesia (Riley, 2010).

As elements of the environment and biodiversity are interconnected, so also can the measurement of certain aspects provide information about others. For example, detecting Coliform bacteria or sampling arthropods such as Odonata which are closely associated with aquatic habitats provide information about water quality (Caro \& Doherty, 1999; Convention on Biological Diversity, 2006). In another instance, comparing small mammal assemblages has helped track how the derived savanna is encroaching into forests in south-western Nigeria (Olayemi \& Akinpelu, 2008). Also, the study of relationships between rock composition and floral and faunal diversity has helped to reveal the association of mosquitoes with rock holes in the Okeiho-Iseyin area of southwestern Nigeria (Ayansola et al., 2003).

The Osun Sacred Forest Grove represents a classic example of where important biological, environmental and cultural values converge to form a special landscape in need of carefully considered conservation. Historically, the Osun River, which runs through Osogbo town, circumscribes the forest grove which the indigenes hold sacred. Hunting of animals and fishing within the river is prohibited by ethnic taboo. In addition, around August every year, the Osun Festival is held in honour of the river goddess, attracting thousands of worshippers and tourists to the grove. From 1960 into the 2000s the Austrian artist, Suzanne Wenger, erected a series of sculptures embedded across the terrain of the grove with motifs in Yoruba traditional myth and religion that enhanced its value as a cultural site of key significance within Osogbo and indeed Nigeria. Ultimately, in 2005, the United Nations Scientific and Cultural Organization (UNESCO) designated the Osun Forest Grove a World Heritage Site.

However, several factors currently threaten the cultural and natural sanctity of Osogbo Sacred Grove. For instance, over the years, Osogbo town has expanded to surround the grove and the pressures of urban development appear to infringe the protected area. Also, there is no information concerning the effect the constant stream of visitors through the year (for spiritual activities and tourism) may have on the grove. There is an urgent need to obtain contemporary data concerning physical, biological and cultural aspects of this protected area.

Therefore it was our aim to conduct a rapid environmental assessment of Osun Sacred Grove in order to provide updated information about its conservation status. More specifically, our objectives were: 1) to plot a digitized map against which key biota and cultural features in the protected area can be referenced; 2) to sample, as indicator taxa, higher and lower plants, arthropods, small mammals and primates; and 3) to determine the water quality of the Osun River in the grove by measuring various physical and microbiological parameters. These results are presented in relation to anthropological threats noticed in the protected area during our sampling.

\section{Methods}

Osun Sacred Grove is located approximately between latitudes $7^{\circ} 44^{\prime} 50.0^{\prime \prime}-7^{\circ} 46^{\prime} 00.0^{\prime \prime} \mathrm{N}$ and longitudes $4^{\circ} 32^{\prime} 40^{\prime \prime}$ - $4^{\circ} 33^{\prime} 40^{\prime \prime}$ E (Figure 1). It is contained within the rainforest zone of south-western Nigeria. This area is characterized by high humidity and rainfall. The mean annual temperature is about $27^{\circ} \mathrm{C}$ and the relative humidity of the area is between $92 \%-99 \%$ (Ola \& Adewale, 2014). The mean annual rainfall is between $1200 \mathrm{~mm}$ and 1450 $\mathrm{mm}$. However, considerable stretches of the original forest have now been replaced by secondary forest and derived savanna (NEST, 2016). The grove covers an area of about 75 hectares with a buffer zone of about 47 hec- 
tares surrounding it.

The buffer zone around the grove features significant anthropogenic influence. It is majorly farmland, cultivated mostly with subsistence crops like maize, beans, cassava, okra and pineapple. Within the buffer zone northward of the Main Gate (Figure 1) is a plantation of Teak (Tectona grandis). Further outside the buffer zone is Osogbo town itself. In this study we comparatively sampled the buffer and outside zones for certain taxa in relation to the grove itself (which we refer to in such cases as the core zone). Field sampling was conducted between $1^{\text {st }}$ and $4^{\text {th }}$ December 2015.

As the vegetation from the buffer zone was predominantly agricultural, only plants from the core zone of the grove were surveyed. Voucher specimens were identified, preserved and deposited in Herbarium of Natural History Museum (UNIFEM), Obafemi Awolowo University, Ile-Ife, Nigeria. Identification was made using herbarium specimens, monograms and available Floras. Tour guides employed at the grove were also interviewed for the medicinal uses of some of the plants collected.

Insects were sampled in the core, buffer and outside zones. They were collected by both direct and indirect methods. The direct methods used in this study include searching and hand picking, sweep and butterfly netting. The indirect methods were with malaise traps, berlese traps, yellow pan traps, light traps and pit fall traps. Insect specimens collected were preserved by wet and dry preservation methods. Dry-preserved specimens were sacrificed with ethyl acetate, dried properly and identified before being stored in insect boxes and cabinets.

Murid rodents, shrews and primates were the mammals surveyed in this study. As collecting vertebrates is prohibited within the grove, small mammals were captured using Sherman traps in the buffer and outside zones. Traps were set in the late afternoon until the morning of the next day. Sighting of primates was carried out while

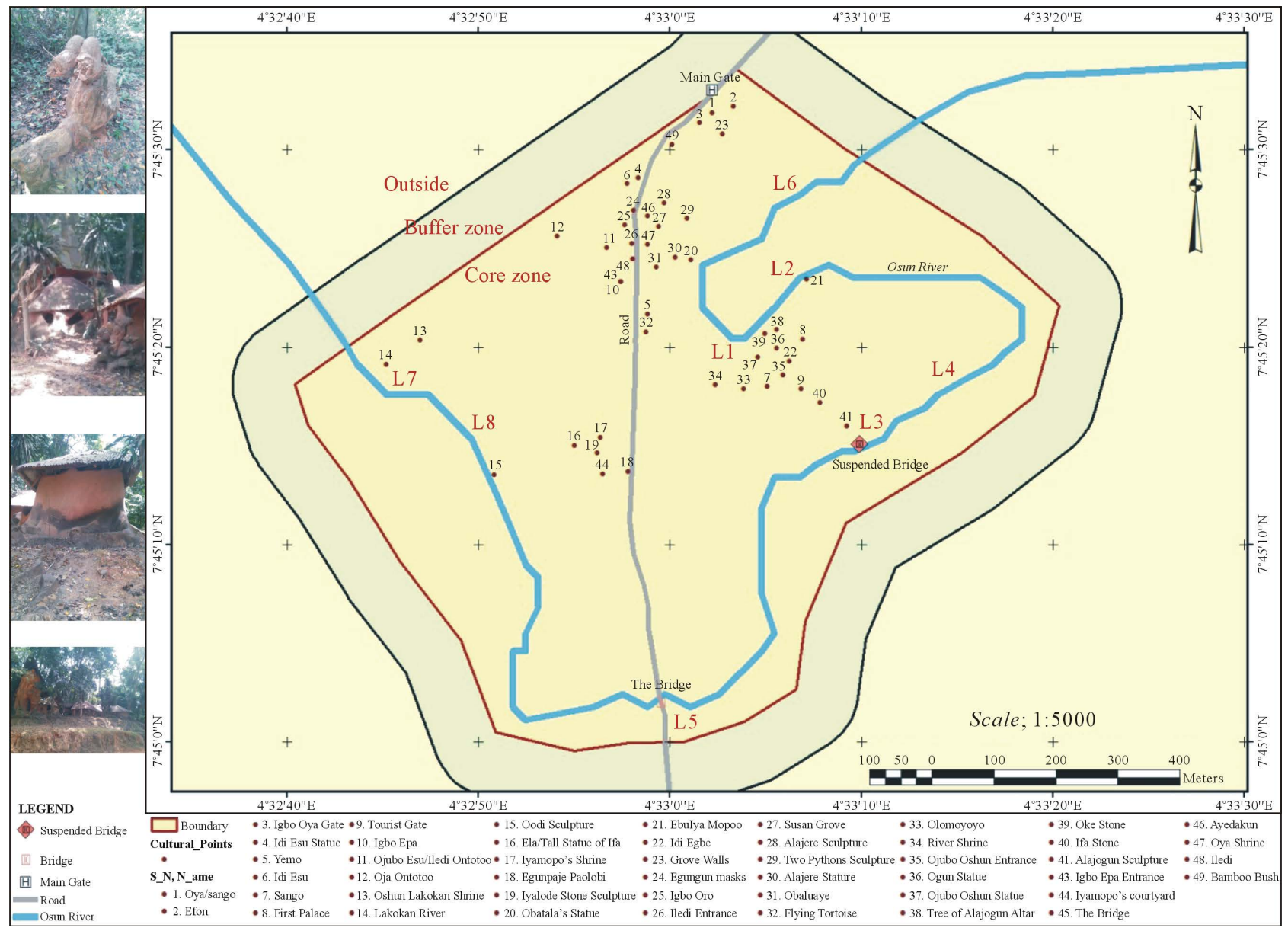

Figure 1. Map of Osun Sacred Grove showing sampling points for various natural and cultural features. Numbered dots indicate sculptures and shrines listed below the map. Insets are photos of some of these shrines, depicting some of the deterioration witnessed during the study. L1 - L8 indicate points at which geological and water samples were taken. 
walking through designated transects that covered most of the core area. Transects were patrolled periodically from early in the morning till late afternoon. The transects, demarcated by taking advantage of the siting of cultural artifacts as represented by points in Figure 1 are the main gate area ( $\left.\sim \mathrm{N}^{\circ} 45^{\prime} 29.1^{\prime \prime} \mathrm{E} 4^{\circ} 32^{\prime} 59.0^{\prime \prime}\right)$; the main reception area, between points 5 and 34 ( $\left.\sim \mathrm{N}^{\circ} 45^{\prime} 20.1^{\prime \prime} \mathrm{E} 4^{\circ} 32^{\prime} 58.4^{\prime \prime}\right)$; the Ojubo Osun area, between points 39 and $41\left(\sim \mathrm{N} 7^{\circ} 45^{\prime} 19.6^{\prime \prime} \mathrm{E} 4^{\circ} 33^{\prime} 60.0^{\prime \prime}\right)$ and the southern bridge area ( N $\left.7^{\circ} 45^{\prime} 03.1^{\prime \prime} \mathrm{E} 4^{\circ} 32^{\prime} 59.6^{\prime \prime}\right)$. The Chi square test was applied to indicate significant differences in primate occurrence across various transects.

Preliminary survey of the rock types was carried out within the Osun Sacred grove. As Osun River strips away the soil it exposes the underlying bedrock, which gives the opportunity to survey the underlying rock types and minerals along the river course.

In order to assess water quality within the grove a total of 8 samples were collected between $9.00-11.00$ am daily from different locations within the core zone (L1-L8; Figure 1). PH, temperature, electrical conductivity and total dissolved solids were determined and recorded immediately at each site using standard methods (APHA, 1998). Microbiological analyses of water samples collected were also carried out in the laboratory. The microbiological analyses conducted include total heterotrophic bacteria, total heterotrophic fungi and Coliform tests.

In accordance with APHA (1998) Heterotrophic Plate Count (HPC) was used to measure bacteriological quality of water samples. Hundredfold serial dilution of each water sample was carried out six times in a set of test-tubes containing $9.9 \mathrm{ml}$ sterile water. $1 \mathrm{ml}$ of each dilution was plated out in duplicates, employing the use of nutrient agar medium. These were kept in molten form. Pour Plate method was adopted. The culture plates were incubated invertedly and aerobically at $35^{\circ} \mathrm{C}$ for 48 hours. The plates were observed for growth and selected for count after expiration of the incubational period. The number of colonies with less 300 and its duplicate for each sample was selected. The count so obtained was multiplied by the dilution factor and expressed as colony forming unit (CFU) $\mathrm{ml}^{-1}$ of the original sample.

The same procedure for the Heterotrophic Plate Count (HPC) was repeated for the fungi count. In this method malt extract agar was employed as the culture medium following APHA (1998). The culture plates were incubated invertedly and aerobically at $30^{\circ} \mathrm{C}$ for 7 days (until the plates showed no further increase in the number of fungal colonies).

Coliform tests were also carried out on the water samples. The most probable number (MPN) of coliform presumptive test was carried out on each of the test samples. The culture tubes were incubated at $35^{\circ} \mathrm{C}$ for 48 hours. After incubation, the numbers of coliform cells present in $100 \mathrm{ml}$ of the original water sample were estimated. Furthermore, confirmatory test was carried out on the water samples for detection of Escherichia coli. Tubes showing gas and/or acid (MPN) were sub-cultured on Eosin Methylene blue (EMB) agar incubated at $35^{\circ} \mathrm{C}$ for 24 hours. The tubes were observed for typical colonies of E. coli. Several typical colonies of E. coli from the EMB plate were sub-cultured into brilliant green broth fermentation tubes and peptone water. The fermentation tubes were incubated at $37^{\circ} \mathrm{C}$ and $44^{\circ} \mathrm{C}$ for 48 hours while that of the peptone water was incubated at $35^{\circ} \mathrm{C}$ for 24 hours.

We also carried out an inventory of artifacts of cultural significance such as shrines and sculptures as they are laid out within the natural habitat of the grove. The relative position for each of these artifacts was recorded in GPS coordinates and plotted on a digital map (Figure 1). Their physical condition (intact, slightly deteriorated or significantly deteriorated) was also noted. Non-structured interviews were conducted with tour guides employed within the grove to assess how the activities of visitors affected these cultural artifacts and also the natural environment.

\section{Results and Discussion}

\subsection{Plants}

As a tropical forest, the vegetation of Osun Sacred Grove is of three layers. The first consisting of herbs, small shrubs and tree seedlings; the second consists of average-height trees and shrubs; the topmost consists of very tall trees of 15-30 $\mathrm{m}$ in height with various girths and with climbers forming a dense or partially dense canopy. The plant species and their families identified during the survey comprise of 74 species of Angiosperm (41 families), 10 species of Pteridophytes ( 5 families), 2 species of Bryophytes ( 2 families), and 2 species of lichens ( 2 families) as shown in Table 1. Soladoye and Oni (1996, cited by NCMM, 2005) reported a higher number of flora species (400) and families (63) in grove. 
Table 1. List of plants identified in the core zone.

\begin{tabular}{|c|c|c|c|c|}
\hline Botanical Name of Plants & Family & Habit/Growth form & Common Name & Local Name \\
\hline \multicolumn{5}{|l|}{ Angiosperms } \\
\hline 1) Acanthospermun hispidum & Asteraceae & Herb & & \\
\hline 2) Acanthus montanus (Nees) T. Anders & Acanthaceae & Herb & False thistle & Ahonekun \\
\hline 3) Adeniacissampeloides & Passifloraceae & Tree & & Arokeke \\
\hline 4) Ageratum conyzoides $\mathrm{L}$. & Asteraceae & Herb & & Imiesu \\
\hline 5) Albizia zygia (DCJ.) F. Macbr. & Mimosaceae & Tree & & \\
\hline 6) Alternanthera pungens H.B.K. & Amaranthaceae & Herb & & \\
\hline 7) Alfzelia africana $\mathrm{Sm}$ & Ceasalpiniaceae & Tree & & Apa \\
\hline 8) Alchornea laxiflora (Benth) Pas \& Hoffin & Euphorbiaceae & Shrub & & \\
\hline 9) Allophyllus africanus P. Beauv. & & Tree & & Eekanehoro \\
\hline 10) Anchomanes difformis Engl. & Araceae & Herb & & OgiriIsako \\
\hline 11) Alstonia boneii De Wild & Apocynaceae & Tree & & Ahun \\
\hline 12) Andropogon tectorum Shum \& Thorn & Poaceae & Grass & & \\
\hline 13) Antiaris toxicaria Lesch. & Moraceae & Tree & & Oro \\
\hline 14) Annona seleganensis & Annonaceae & Tree & & \\
\hline 15) Aristolochia ringes Vahl & Ariostolochiaceae & Climber & & \\
\hline 16) Aspilia Africana (Pers) C.D.Adams & Apocynaceae & Herb & & \\
\hline 17) Bambusa vulgaris Schrad. ex J.C. Wendl & Poaceae & & Bamboo & Oparun \\
\hline 18) Baphia nitida Lodd & Papilionaceae & Tree & & Irosun \\
\hline 19) Blepharis maderaspertensis & Asteraceae & Herb & & Ojusaju \\
\hline 20) Blighia sapida Loveth. & Sapindaceae & Tree & & Isin \\
\hline 21) Brachystegia eurycoma Harms & Caesalpiniaceae & Ako & & \\
\hline 22) Bridelia micrantha (Hoschst) Baill. & Euphorbiaceae & Tree & & Ire \\
\hline 23) Cactus feruginea & Cornaraceae & Herb & & \\
\hline 24) Carpolobia lutea (G. Don) & Polygalaceae & Shrub & & Osunsun \\
\hline 25) Chasmanthera dependes Hochst. & Menispermaceae & Tree & & \\
\hline 26) Chrysophyllum albidum G. don & Sapotaceae & Tree & & Agbalumo \\
\hline 27) Ceiba petandra (L.) Gaertn & Bombaceae & Tree & & Araba \\
\hline 28) Celtiszenkeri Engel. & Ulmaceae & Tree & & Ita \\
\hline 29) Centrosema pubescens Benth & Papilionaceae & Climber & & EwuAhun \\
\hline 30) Chromolaena odoratum (L.) & Asteraceae & Herb & & Akintola \\
\hline 31) Cissus petiolata Hook. & Vitaceae & Climber & & \\
\hline 32) Cnestis ferruginea D.C. & Comaraceae & & & \\
\hline 33) Cola milleni K.Shcum & Sterculaceae & Tree & & Obi edun \\
\hline
\end{tabular}




\section{Continued}

34) Combretum bracteatum Engl. \& Diels

Commelinaceae

36) Commelina diffusa Burm.

37) Crotalaria retusa L.

38) Delonix regia (Boj ex Hook)

39) Drycaena fragrans (L.) Ker Gawl.

40) Elaeis guineensis Jacq.

41) Euphorbia hirta L.

42) Euphorbia heterophylla L.

43) Ficus exasperata Vahl.

44) Funtumia elastica (Preuss) Stapf.

45) Gliricidia sepium Jacq.

46) Grewia mollis Juss

47) Grewia capinifolia Juss

48) Gomphrena celosoides Mart.

49) Gmelina arborea Rosb.

50) Icacina trichantha Oliv.

51) Jatropha curcas L.

52) Jatropha podagrica L.

53) Lannea welwitschii (Hien) Engler

54) Lecamniodiscus cuscupaniode Planch ex Bth.

55) Lonchocarpus cyanescens Benth

56) Napoleona vogelii Hook \& Planch

57) Newboudia laevis (P. Beauv) Seem. ex Bur.

58) Milicia excelsa (Welw) C. C. Berg

59) Morinda lucida Benth.

60) Mormodica charantia L.

61) Myrianthus arboreus P. Beauv

62) Nerium oleander L.

63) Olax subscorpioidea Oliv.

64) Pterocarpus osun Craib

65) Rauvolfia vomitora Afzel

66) Sansieviera liberica Gerome \& Labroy

67) Spigelia anthelmia L.

68) Spondias mombin L.
Combretaceae

Combretaceae

Liane

Liane

Herb

Fabaceae

Fabaceae

Asparagaceae

Asteraceae

Euphorbiaceae

Euphorbiaceae

Moraceae

Apocynaceae

Papilionaceae

Tiliaceae

Malvaceae

Amaranthaceae

Verbanaceae

Icacinaceae

Euphorbiaceae

Euphorbiaceae

Anarcadiaceae

Sapindaceae

Fabaceae

Lecythidaceae

Bignonaceae

Moraceae

Rubiaceae

Curcubitaceae

Moraceae

Apocynaceae

Olaeceae

Fabaceae

Apocynaceae

Liliaceae

Euphorbiaceae

Anarcadiaceae
Shrub

Tree

Tree

Tree

Herb

Herb

Tree

Tree

Tree

Tree

Tree

Herb

Tree

Shrub

Shrub

Shrub

Tree

Tree

Shrub

Tree

Tree

Tree

Tree

Herb

Tree

Shrub

Shrub

Tree

Tree

Shrub

Herb

Tree
Ogandudu

Ogandudu

\section{Rattle weed}

Flamboyant

Sekeseke

Peregun

Ope

Asthma plant

Sand paper tree

Eepin/ipin

Agunmaniye

Ora-igbo

Itakunokere

Irawoile

Gbegbe

Opon

Akika

Elu

Ito

Akoko

Iroko

Oruwo

Ejinrin

Oleander

Ifon

Asofeyeje

Ojalkoko

Pink weed

Iyeye 


\section{Continued}
69) Synedrella nodiflora Gaertn
70) Tectona grandis $L$.
71) Tithonia diversifolia (Hemsl.) A. Gray)
72) Tridax procumbens $\mathrm{L}$.
73) Triplochiton scleroxylon K. Schum.
74) Zanthoxylum xanthoxyloides (Lam.)

Asteraceae

Herb

Starwart

Verbanaceae

Tree

Asteraceae

Tree

Asteraceae

Herb

Sterculaceae

Tree

Arere

Rutaceaea

Tree

Ata

Pteridophytes

1) Asplenium trichomanes L.

Aspleniaceae

2) Dryopteris nicklesii Turd

Aspleniaceae

3) Cyclosorus afer (Christ) Ching

Dryopteridaceae

4) Nephrolepis biserrata (Sw.) Schott

Thylepteridaceae

5) Nephrolepis undulate Afzelius ex. Sw

Dryopteridaceae

6) Pityrogramma calomelanos L.

Dryopteridaceae

7) Platycerium stemaria (P. Beauv) Desv

Polypodiaceae

8) Pteris togoensis Hieron

Pteridaceae

9) Pteris mildbraedii L.

Pteridaceae

10) Pteris artrovirens Bak.

Pteridaceae

Bryophytes

1) Racopilum africanum Mitt.

Racopilaceae

2) (unidentified*)

Lichens

1) Hypogymnia physodes (L) $\mathrm{Nyl}$

Paemeliaceae

Foliose

2) Lepraria incana

Stereocaulaceae

Leprose

Dust lichen

The lower number of plant species recorded in this study could be due to the fact that our sampling was within a limited period that is typical of rapid assessment schemes. Still, our survey reveals a range of plant diversity that is worth preserving, especially those identified to possess medicinal and other ethno-botanical properties (Table 2). From our observations during sampling, even this pool of floral genetic resources is at risk. The Osun-Osogbo grove is currently going through pressures from expansion of the human communities around it. Pressures are mostly from deforestation due to farming activities especially at the buffer zones, and also from illegal harvest of plants materials for medicinal purposes and for fuel.

\subsection{Insects}

To our knowledge there has been no definite and comprehensive information to date published on the biodiversity and abundance of insects in Osun Sacred grove. One hundred and eight insect families belonging to 17 different orders of insects were recorded during this study (Table 3). In this study, the core zone has the highest number of 91 insect families (Figure 2), followed by buffer zone with 83 and outside zone has the least number of 63 insect families. Figure 2 also shows the diversity of Hymenoptera in Osun grove. The core zone has the highest diversity index of 0.88 with distribution range of 1.5 . The buffer zone has diversity index of 0.68 with a distribution range of 2 . The outside zone has the lowest diversity index of 0.45 with distribution range of 2 . 
Table 2. Some Medicinal Plants identified in the Osun Grove and their uses.

\begin{tabular}{|c|c|c|}
\hline Name of Plants & Local names & Medicinal uses \\
\hline Alchornea laxiflora & Pepe, Ijan & Leaves for pile; roots boiled as blood tonic \\
\hline Dracaena fragrans & Peregun & Leaves for high fever \\
\hline Cola milleni & Obi edun & Boosting sperm cells \\
\hline Mormordica charantia & Ejinrin & Leaves for pile, stomachache \\
\hline Morinda lucida & Oruwo & Leaves as antimalarial \\
\hline Lonchocarpus cyanescens & Elu & For treating pile; also for treating yaws, leprosy and skin diseases. \\
\hline Ceiba petandra & Araba & Reliefs of Dysmenorrhea \\
\hline Grewia carpinnifolia & Itakunokere & Boosting sperm count \\
\hline Milicia excelsia & Iroko & Bark as antimalarial \\
\hline Rauvolfia vomitora & Asofeyeje & Bark for diabetic and malaria; as sedative and treating menstrual disorder. \\
\hline Anchomanes difformis & Ogiriisako & Tubers for treating measles, cough \\
\hline Olax subscorpioidea & Ifon & Stem for treating tooth decay \\
\hline Zanthoxylum zanthoxyloides & Ata & For treating tooth ache \\
\hline
\end{tabular}

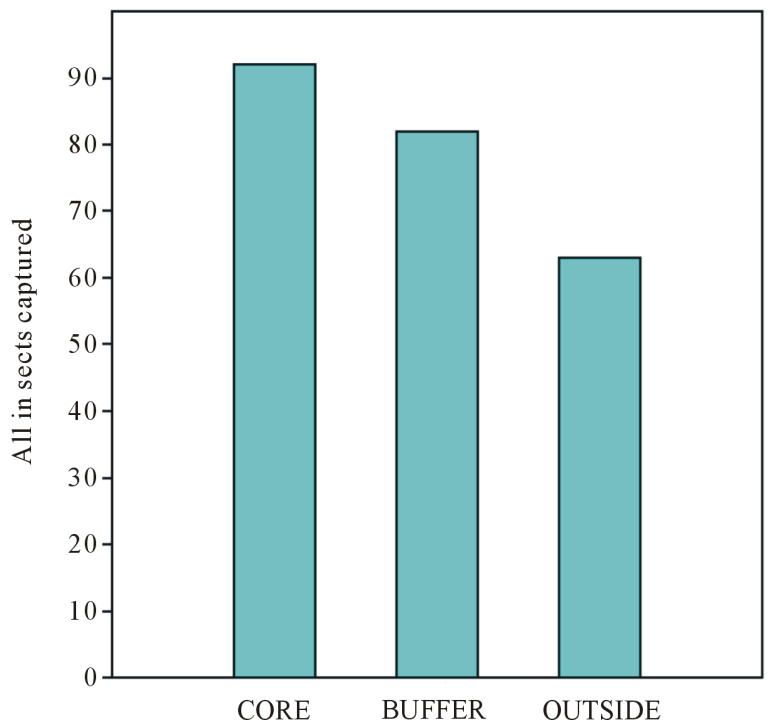

(a)

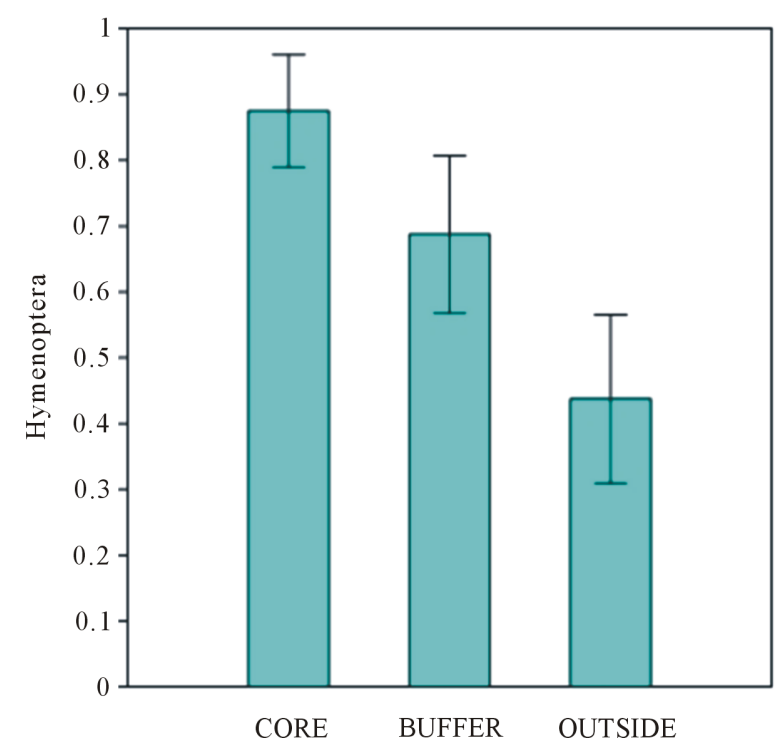

(b)

Figure 2. Distribution of the diversity of insects generally (a) and Hymenoptera (b) across various sampling zones in Osun Sacred Grove and its environs.

The presence of Osun river which runs through the grove could explain the high occurrence of Odonata and Ephemeroptera in core and buffer zones (Table 3). Muscidae is the family of flies; they need to live around plant or manure like cattle dung that was observed in buffer zone. Muscidae laid their eggs on decaying plant materials or manure and were seen in all the three zones (Table 3). The insect abundance that was observed generally in the grove and its surroundings is mostly likely due to rich plant community in the zone. Plant community productivity in the core zone influences insect abundance in the zone and this is in accordance with the study of Perner et al. (2005). The reduction in the diversity of order Hymenoptera, pollinators and flower-visiting insects, in the outside zone (Figure 2) could be due to habitat fragment by cattle grazing and agricultural land use as it was observed in the study of Wenninger and Inouye (2008) and Williams and Kremen (2007). 
Table 3. Insect families captured in Osun Grove. "X" means a particular insect family was present.

\begin{tabular}{|c|c|c|c|c|c|c|c|}
\hline Insect family & Core zone & Buffer zone & Outside zone & Insect family & Core zone & Buffer zone & Outside zone \\
\hline \multicolumn{8}{|c|}{ Order Hymenoptera } \\
\hline Pergidae & $\mathrm{X}$ & $\mathrm{X}$ & $\mathrm{X}$ & Ichneumonidae & $\mathrm{X}$ & $\mathrm{X}$ & $\mathrm{X}$ \\
\hline Siricidae & & $\mathrm{X}$ & & Braconidae & $\mathrm{X}$ & & \\
\hline Argidae & $\mathrm{X}$ & $\mathrm{X}$ & $X$ & Chrysididae & $\mathrm{X}$ & & \\
\hline Cimbicidae & $\mathrm{X}$ & & & Pelecinidae & $X$ & & \\
\hline Formicidae & $\mathrm{X}$ & $\mathrm{X}$ & $\mathrm{X}$ & Sphecidae & $\mathrm{X}$ & & \\
\hline Evaniidae & $\mathrm{X}$ & $\mathrm{X}$ & $\mathrm{X}$ & Vespidae & $\mathrm{X}$ & $\mathrm{X}$ & $X$ \\
\hline Aphelenidae & $\mathrm{X}$ & $\mathrm{X}$ & & Tiphiidae & & $X$ & \\
\hline Gasteruptiidae & $\mathrm{X}$ & $X$ & $\mathrm{X}$ & Megachildae & $\mathrm{X}$ & $\mathrm{X}$ & \\
\hline \multicolumn{8}{|c|}{ Order Diptera } \\
\hline Tipulidae & $\mathrm{X}$ & $\mathrm{X}$ & $\mathrm{X}$ & Asilidae & $\mathrm{X}$ & $\mathrm{X}$ & $\mathrm{X}$ \\
\hline Cecidomyiidae & & & $\mathrm{X}$ & Bombyliidae & & $\mathrm{X}$ & $\mathrm{X}$ \\
\hline Simulidae & & $\mathrm{X}$ & $\mathrm{X}$ & Drosophilidae & & $\mathrm{X}$ & $\mathrm{X}$ \\
\hline Chironomidae & & $X$ & & Tephritidae & $X$ & $X$ & $X$ \\
\hline Culicidae & $\mathrm{X}$ & $\mathrm{X}$ & $\mathrm{X}$ & Muscidae & $\mathrm{X}$ & $\mathrm{X}$ & $\mathrm{X}$ \\
\hline Dixidae & & $\mathrm{X}$ & $\mathrm{X}$ & Anthomyiidae & $\mathrm{X}$ & $\mathrm{X}$ & $\mathrm{X}$ \\
\hline Tabanidae & & $X$ & $X$ & Calliphoridae & $X$ & $X$ & $X$ \\
\hline Stratiomydae & $\mathrm{X}$ & $\mathrm{X}$ & $X$ & Sarcophagidae & & $X$ & $\mathrm{X}$ \\
\hline \multicolumn{8}{|c|}{ Order Lepidoptera } \\
\hline Papilionidae & $\mathrm{X}$ & $\mathrm{X}$ & $X$ & Psychidae & $\mathrm{X}$ & & \\
\hline Satyridae & $X$ & $\mathrm{X}$ & $X$ & Sphingidae & $X$ & $\mathrm{X}$ & $X$ \\
\hline Pieridae & $\mathrm{X}$ & $\mathrm{X}$ & $\mathrm{X}$ & Limacodidae & $\mathrm{X}$ & $\mathrm{X}$ & $\mathrm{X}$ \\
\hline Nymphalidae & $\mathrm{X}$ & $\mathrm{X}$ & $\mathrm{X}$ & Saturniidae & $\mathrm{X}$ & $\mathrm{X}$ & $\mathrm{X}$ \\
\hline Sesiidae & $X$ & & $X$ & Noctuidae & $\mathrm{X}$ & & \\
\hline Pterophoridae & $\mathrm{X}$ & $\mathrm{X}$ & & Tinneidae & $\mathrm{X}$ & $X$ & \\
\hline Pyralidae & $\mathrm{X}$ & $\mathrm{X}$ & & Coleophoridae & $\mathrm{X}$ & $\mathrm{X}$ & $\mathrm{X}$ \\
\hline \multicolumn{8}{|c|}{ Order Coleoptera } \\
\hline Carabidae & $X$ & $\mathrm{X}$ & $X$ & Dermestidae & $\mathrm{X}$ & $X$ & $\mathrm{X}$ \\
\hline Dystiscidae & & $\mathrm{X}$ & $\mathrm{X}$ & Buprestidae & $\mathrm{X}$ & $X$ & \\
\hline Gyrinidae & & $\mathrm{X}$ & $\mathrm{X}$ & Tenebrionidae & $\mathrm{X}$ & $X$ & \\
\hline Scarabaeidae & $\mathrm{X}$ & $\mathrm{X}$ & $\mathrm{X}$ & Cerambycidae & $\mathrm{X}$ & $\mathrm{X}$ & \\
\hline Silphidae & $\mathrm{X}$ & $\mathrm{X}$ & $\mathrm{X}$ & Bruchidae & $\mathrm{X}$ & $\mathrm{X}$ & $\mathrm{X}$ \\
\hline Hydrophilidae & $\mathrm{X}$ & $\mathrm{X}$ & & Chrysomelidae & $\mathrm{X}$ & $\mathrm{X}$ & $\mathrm{X}$ \\
\hline Byturidae & $\mathrm{X}$ & $\mathrm{X}$ & $\mathrm{X}$ & Curculionidae & $\mathrm{X}$ & $\mathrm{X}$ & $\mathrm{X}$ \\
\hline Helodidae & $\mathrm{X}$ & & & Anthribidae & $\mathrm{X}$ & $\mathrm{X}$ & \\
\hline Elateridae & $X$ & $\mathrm{X}$ & & Brentidae & $\mathrm{X}$ & & \\
\hline
\end{tabular}




\section{Continued}

\begin{tabular}{|c|c|c|c|c|c|c|c|}
\hline \multicolumn{8}{|c|}{ Order Heteroptera } \\
\hline Belostomatidae & $\mathrm{X}$ & $\mathrm{X}$ & & Anthocoridae & $\mathrm{X}$ & $\mathrm{X}$ & \\
\hline Nepidae & $\mathrm{X}$ & $\mathrm{X}$ & $\mathrm{X}$ & Reduviidae & $\mathrm{X}$ & $\mathrm{X}$ & \\
\hline Gelastocoridae & $\mathrm{X}$ & & & Tingidae & $\mathrm{X}$ & & \\
\hline Corixidae & $\mathrm{X}$ & $\mathrm{X}$ & & Miridae & $\mathrm{X}$ & $\mathrm{X}$ & $\mathrm{X}$ \\
\hline Notonectidae & $\mathrm{X}$ & $\mathrm{X}$ & $\mathrm{X}$ & Lygaeidae & & & $\mathrm{X}$ \\
\hline Gerridae & & $\mathrm{X}$ & $\mathrm{X}$ & Pentatomidae & $\mathrm{X}$ & $\mathrm{X}$ & $\mathrm{X}$ \\
\hline \multicolumn{8}{|c|}{ Order Homoptera } \\
\hline Cicadidae & $X$ & $\mathrm{X}$ & $\mathrm{X}$ & Aleyrodidae & $\mathrm{X}$ & $\mathrm{X}$ & $\mathrm{X}$ \\
\hline Membracidae & $\mathrm{X}$ & & & Aphididae & $\mathrm{X}$ & $\mathrm{X}$ & \\
\hline Cicadellidae & $\mathrm{X}$ & & & Kerridae & $\mathrm{X}$ & & \\
\hline Fulgoridae & $X$ & & & Coccidae & $\mathrm{X}$ & & \\
\hline Issidae & $\mathrm{X}$ & $\mathrm{X}$ & & Pseudococcidae & $\mathrm{X}$ & & \\
\hline Psyllidae & $\mathrm{X}$ & $\mathrm{X}$ & $\mathrm{X}$ & & & & \\
\hline \multicolumn{8}{|c|}{ Order Isoptera } \\
\hline Kalotermitidae & $\mathrm{X}$ & & $\mathrm{X}$ & Termitidae & $\mathrm{X}$ & $\mathrm{X}$ & $\mathrm{X}$ \\
\hline Rhinotermitidae & $\mathrm{X}$ & $X$ & & & & & \\
\hline \multicolumn{8}{|c|}{ Order Dermaptera } \\
\hline Labiidae & $\mathrm{X}$ & & & & & & \\
\hline \multicolumn{8}{|c|}{ Order Mantodea } \\
\hline Mantidae & $\mathrm{X}$ & $\mathrm{X}$ & $\mathrm{X}$ & & & & \\
\hline \multicolumn{8}{|c|}{ Order Blattaria } \\
\hline Blattidae & $\mathrm{X}$ & $\mathrm{X}$ & $\mathrm{X}$ & Blattelidae & $\mathrm{X}$ & & $\mathrm{X}$ \\
\hline \multicolumn{8}{|c|}{ Order Phasmida } \\
\hline Phasmatidae & $\mathrm{X}$ & $\mathrm{X}$ & $\mathrm{X}$ & & & & \\
\hline \multicolumn{8}{|c|}{ Order Orthoptera } \\
\hline Acrididae & $\mathrm{X}$ & $\mathrm{X}$ & $\mathrm{X}$ & Tettigoniidae & $\mathrm{X}$ & $\mathrm{X}$ & $\mathrm{X}$ \\
\hline Gryllidae & & $\mathrm{X}$ & $\mathrm{X}$ & Gryllotalpidae & & & $\mathrm{X}$ \\
\hline Tetrigidae & $\mathrm{X}$ & $\mathrm{X}$ & $\mathrm{X}$ & & & & \\
\hline \multicolumn{8}{|c|}{ Order Plecoptera } \\
\hline Capniidae & $\mathrm{X}$ & $\mathrm{X}$ & $\mathrm{X}$ & & & & \\
\hline & & & & goptera & & & \\
\hline Coenagrionidae & $\mathrm{X}$ & $\mathrm{X}$ & & & & & \\
\hline \multicolumn{8}{|c|}{ Order Odonata } \\
\hline Libellulidae & $\mathrm{X}$ & $\mathrm{X}$ & & Macromiidae & & $\mathrm{X}$ & \\
\hline Aeshnidae & $\mathrm{X}$ & $\mathrm{X}$ & & & & & \\
\hline \multicolumn{8}{|c|}{ Order Thysanura } \\
\hline Lepismatidae & $\mathrm{X}$ & & & & & & \\
\hline \multicolumn{8}{|c|}{ Order Collembola } \\
\hline Sminthuridae & $\mathrm{X}$ & $\mathrm{X}$ & & Isotomidae & $\mathrm{X}$ & $\mathrm{X}$ & $\mathrm{X}$ \\
\hline
\end{tabular}




\subsection{Mammals}

Nine small mammal specimens were captured in the buffer and outside zones (as trapping of mammals is prohibited within the grove). These are made up of 3 species, which are the Multimammate rat Mastomys natalensis, the Pygmy mouse Mus (Nannomys) setulosus and Olivier's shrew Crocidura olivieri (Table 4). Two of these species, Mastomys natalensis and Crocidura olivieri, have been described by Happold (2013) as commensal. They were captured near human dwellings in the outside zone and also in the buffer zone, which is comprised of mostly agricultural vegetation. Mus setulosus was captured only in the buffer zone. Olayemi and Akinpelu (2008) demonstrated the encroachment of derived savanna into the rainforest zone within southwestern Nigeria using rodents as indicator species. Though we could not trap small mammals within the core zone, results in this study display a similar pattern. Encroachment of the buffer and outside zones will likely lead to a depletion of small mammal diversity within the core zone, resulting in an assemblage comprised of few species reflective of heavy human influence.

Concerning primates, a total of 289 sightings were made within the core zone. All specimens were Mona monkeys Cercopithecus mona, identified based on external morphological features published in Butynski et al. (2013). This contrasts a previous report by Babalola et al. (2014) that the White throated monkey (Guenon cercopithecus erythrogaster) is the dominant primate within Osun grove. We did not encounter this latter species during this survey.

From Table 4, a significantly higher average number per day of the Mona monkeys were sighted in the main reception area where the most human activity was observed compared to other transects within the core zone $\left(\chi^{2}\right.$ test, $p<0.001)$. Babalola et al. (2014) also observed a concentration of primate abundance around the shrines. In addition, during our sampling we noticed visitors feeding the monkeys bananas and other tidbits, an act that constitutes human interference in the natural ecosystem of Osun grove. If this particular interference is not controlled there is the danger that the Mona monkey population could explode to dominate the mammal community and cause ecological imbalance, affecting other biological components of the grove adversely.

\subsection{Geology of Osun River Bedrock and Water Quality}

An inventory of the rock types of Osun Osogbo grove reveals that two types occur. These are the Granite gneiss and Granite pegmatite rocks. They outcrop in locality one, Ibu Ojubo (L1, Figure 1), locality three, Suspended Bridge (L3) and locality seven, Lakokan (L7). Outcrop exposures within the sacred grove are generally poor and are only encountered along the course of Osun River. In addition, presences of some rock-forming minerals are observed on the rocky outcrops (Table 5). Both rocks are members of the Nigerian Basement Complex that dominates South Western Nigeria (Obaje, 2009), which forms a fraction of the Pan-African mobile belt, and reclines between the West African and Congo Cratons and south of the Tuareg Shield (Black, 1980). Olajire and Imeokparia (2000) reported the exposure of Pre-Cambrian rocks from the river Osun's catchment area. These rock types are believed to have weathered into clayey-loamy soil that was observed in the surrounding of the sacred grove site (McLean \& Gribble, 1990).

Table 6 shows the physical parameters of the water samples from the eight sampling locations (L1 - L8). The temperature of the water ranged from $25.3^{\circ} \mathrm{C}$ to $31.5^{\circ} \mathrm{C}$. Microorganisms thrive at high temperature. More specifically, the optimum temperature required for the growth of E. coli is $37^{\circ} \mathrm{C}$ (Elsas et al., 2011). The study revealed that the growth rate of microorganisms in the water will be slow at the various temperatures recorded. The $\mathrm{pH}$ values of the water ranged from slightly acidic to slightly alkaline (6.5 to 7.8). The $\mathrm{pH}$ values of all the

Table 4. Mammals encountered during the study.

\begin{tabular}{|c|c|c|c|c|c|c|c|}
\hline \multirow{2}{*}{$\begin{array}{l}\text { No. of primates } \\
\text { (Cercopithecus mona) sighted }\end{array}$} & \multicolumn{4}{|c|}{ Core Zone } & \multirow{2}{*}{$\begin{array}{l}\text { No. of small } \\
\text { mammals trapped }\end{array}$} & \multirow{2}{*}{$\begin{array}{l}\text { Buffer } \\
\text { zone }\end{array}$} & \multirow{2}{*}{$\begin{array}{l}\text { Outside } \\
\text { zone }\end{array}$} \\
\hline & Day 1 & Day 2 & Day 3 & Average & & & \\
\hline Main gate area & 28 & 8 & 20 & 18.66 & Crocidura olivieri & 2 & 3 \\
\hline Main reception area & 41 & 70 & 42 & 51 & Mastomys natalensis & & 3 \\
\hline Ojubo Osun area & 17 & 9 & 14 & 13.33 & Mus setulosus & 1 & \\
\hline Southern bridge area & 4 & 11 & 25 & 13.33 & & & \\
\hline
\end{tabular}


Table 5. General rock and mineral diversity in Osun sacred Grove*.

\begin{tabular}{ccc}
\hline Sampling site & Rock Occurrences & Mineral Occurrences \\
\hline L1 & Granite gneiss (R) & Qtz (F), Fsp (F), and Bt (F) \\
L2 & Nil & Qtz (F) \\
L3 & Granite pegmatite (R) & Qtz (F), Fsp (F), and Bt (F) \\
L4 & Nil & Qtz (F) \\
L5 & Nil & Qtz (F) \\
L6 & Nil & Qtz (F) \\
L7 & Granite gneiss (R) & Qtz (F), Fsp (F), and Bt (F) \\
L8 & Nil & Qtz (F) \\
\hline
\end{tabular}

${ }^{*} \mathrm{Bt}=$ Biotite, Fsp = Feldspar (orthoclase), $\mathrm{Qtz}=$ Quartz, $\mathrm{R}=$ Rare and F = Few (Kretz, 1983; Mandarino, 1999; Mandarino and Back, 2004).

Table 6. Physical properties of Osun Osogbo water samples.

\begin{tabular}{ccccc}
\hline & \multicolumn{4}{c}{ Physical-chemical parameters of water samples } \\
\cline { 2 - 5 } Sampling site & $\mathrm{P}^{\mathrm{H}}$ & $\begin{array}{c}\text { Temperature } \\
\left({ }^{\circ} \mathrm{C}\right)\end{array}$ & $\begin{array}{c}\text { Conductivity } \\
(\mathrm{ms} / \mathrm{cm})\end{array}$ & $\begin{array}{c}\text { Total Dissolved } \\
\text { Solids (TDS) } \\
(\mathrm{ppm})\end{array}$ \\
\hline L1 & 7.3 & 27.7 & 0.09 & 068 \\
L2 & 7.6 & 27.5 & 0.12 & 106 \\
L3 & 7.8 & 26.3 & 0.15 & 110 \\
L4 & 7.4 & 25.3 & 0.06 & 054 \\
L5 & 6.5 & 31.5 & 0.15 & 104 \\
L6 & 7.8 & 26.5 & 0.15 & 145 \\
L7 & 7.8 & 25.5 & 0.12 & 098 \\
L8 & 7.8 & 26.3 & 0.12 & 106 \\
\hline
\end{tabular}

water samples is within the range of 6 to 9 set by World Health Organization (WHO, 2008) for drinking water. This implies that the $\mathrm{pH}$ value of the water is suitable for recreational, domestic and agricultural uses. The electrical conductivity of the water samples is between the ranges of 0.06 to $0.15 \mathrm{~ms} / \mathrm{cm}$ (Table 6). It shows the level of concentration of ions in the water. The Total Dissolved Solids (TDS) of the water samples in the area are between 054 to $145 \mathrm{ppm}$. The TDS values were lower than $500 \mathrm{mg} / \mathrm{l}$ limit set by WHO (2008) for drinking water.

The results of the microbiological analysis of the water samples are presented in Table 7. The total heterotrophic bacteria plate count ranged from $4.0 \times 10^{4} \mathrm{cfu} / \mathrm{ml}$ to $1.14 \times 10^{3} \mathrm{cfu} / \mathrm{ml}$. All the water samples had heterotrophic plate count (HPC) higher than the WHO (2008) primary drinking water standard of $100 \mathrm{cfu} / \mathrm{ml}$ when incubated at $35^{\circ} \mathrm{C}$. This implies that heterotrophic bacteria are present in the water. The high HPC count in all the eight water samples is an indicator for ideal conditions for the growth of more dangerous bacteria such as Lingionella or Escherichia coli which are disease-causing bacteria. In addition, high concentration of heterotrophic bacteria in the water samples implies that the water is not suitable for drinking and various domestic uses at its present state. The presence of high concentration of heterotrophic bacteria in the water can be linked to pollution of the river through unsustainable human activities (grazing of animals, farming, washing of clothes and construction of roads and bridges). Therefore, the water is contaminated and may pose health risks to humans if used without treatment. 
Table 7. Microbiological analyses of Osun Osogbo water samples.

\begin{tabular}{|c|c|c|c|c|c|}
\hline \multirow{2}{*}{ Sampling site } & \multirow{2}{*}{$\begin{array}{c}\text { THB at } 35^{\circ} \mathrm{C} \\
(\mathrm{CFU} / \mathrm{ml})\end{array}$} & \multicolumn{3}{|c|}{ Coliform Tests } & \multirow{2}{*}{$\begin{array}{c}\mathrm{THF} \text { at } 30^{\circ} \mathrm{C} \\
(\mathrm{CFU} / \mathrm{ml})\end{array}$} \\
\hline & & Coli MPN (cells/100ml) & Confirmatory & Completed & \\
\hline L1 & $4.0 \times 10^{4}$ & $2.4 \times 10^{2}$ & ECP* & + & $1.0 \times 10^{2}$ \\
\hline $\mathrm{L} 2$ & $5.2 \times 10^{5}$ & $1.1 \times 10^{3}$ & ECP & ++ & $3.0 \times 10^{2}$ \\
\hline L3 & $3.6 \times 10^{5}$ & $4.6 \times 10^{2}$ & $\mathrm{ECP}$ & + & $7.0 \times 10^{4}$ \\
\hline L4 & $5.8 \times 10^{5}$ & 36.0 & ECP & + & $4.0 \times 10^{2}$ \\
\hline L5 & $3.3 \times 10^{5}$ & $2.1 \times 10^{2}$ & ECNP & NA & $3.0 \times 10^{2}$ \\
\hline L6 & $5.0 \times 10^{4}$ & 15.0 & ECNP & NA & $1.4 \times 10^{5}$ \\
\hline L7 & $3.3 \times 10^{5}$ & $1.2 \times 10^{2}$ & $\mathrm{ECP}$ & ++ & $9.0 \times 10^{2}$ \\
\hline L8 & $1.14 \times 10^{5}$ & $4.6 \times 10^{2}$ & $\mathrm{ECP}$ & ++ & $6.0 \times 10^{2}$ \\
\hline
\end{tabular}

The number of coliform cells present in the water samples ranged from 15.0 cells $/ 100 \mathrm{ml}$ to $1.1 \times 10^{3}$ cells/100ml (Table 7). WHO (2008) recommends that total coliforms should not be present in drinking water. The high numbers of total coliforms indicate that pathogenic organisms are present in the water samples. It also implies that the water is contaminated. Faecal coliforms (FC) were detected in six of the water samples (L1, L2, L3, L4, L7, L8). Three of the eight water samples (L1, L3, L4) tested positive for FC at $37^{\circ} \mathrm{C}$, another three of the water samples (L2, L7, L8) tested positive at both $37^{\circ} \mathrm{C}$ and $44^{\circ} \mathrm{C}$ for $\mathrm{FC}$ while two of the water samples (L5, L6) showed that FC are not present in the water (Table 7). WHO (2008) recommends zero E. coli per $100 \mathrm{ml}$ of water. The positive tubes at $37^{\circ} \mathrm{C}$ implies that $E$. coli. present in the water might have gone through mutation. The positive tubes incubated at both $37^{\circ} \mathrm{C}$ and $44^{\circ} \mathrm{C}$ is an indication of faecal coliform that occurs normally in human and animal intestines. Their presence in the water samples indicates recent contamination with faeces as reported by Ashbolt et al. (2001).

Notably, one of the harmful pathogenic strains, E. coli O157:H7 are known to be found in cow intestines. Escherichia coli O157:H7 produces a powerful toxin that can cause severe illness (Lejeune et al., 2001; Habteselassie et al., 2010). There is a high tendency that the introduction of faecal coliform into the river is as a result of continuous grazing of cows in the buffer and outside zones of the grove. Escherichia coli O157:H7 have adverse effects on human health, affect animals and contaminates plants by interacting with plants cells especially when the contaminated water is used for agricultural purposes. Consumption of water contaminated with either human or animal faeces can result into urinary tract infections, waterborne disease such as cholera, diarrhea and typhoid according to WHO (2008). The water can also act as a carrier of other parasitic infections such as $b a$ lantidias (Balantidium coli) and certain helminths. Furthermore, poliomyelitis (polio) may be contacted if the water is contaminated by the faeces of a person infected by poliovirus. The detection of faecal coliforms in the water samples implies that the water is contaminated and is not safe for drinking or domestic, agricultural and recreational activities without treatment.

The Total Heterotrophic Fungi (TBF) count of the water samples is between the ranges of $1.0 \times 10^{2} \mathrm{cfu} / \mathrm{ml}$ to $1.4 \times 10^{5} \mathrm{cfu} / \mathrm{ml}$ (Table 7). This shows that a high population of heterotrophic fungi is presence in the water which is against the standards acceptable by WHO (2008) for drinking water. WHO (2008) recommends that fungi should not be present in drinking water. The occurrence of fungi in the water samples may be due to large amounts of organic matter from plants, environmental pollutants and agricultural crops. Organic matter is known to provide nutrients for fungal growth as reported by the Department for environment, Food and Rural Affairs (2011). The presence of fungi in water can cause odor and severe fungal infections if consumed without treatment.

\subsection{Cultural Artifacts}

There are over 40 sculptured images of deities in different postures and undertaking various chores within the sacred grove. There are also several shrines placed in specific areas of the grove, connoting a unity of purpose of the deities. All these allow the grove to be aptly described as a repository of the tangible and intangible cultural 
heritage of the Osogbo people, a feat that Wenger carried out singularly to protect the sacredness of the grove (Wenger, 1990).

A map was plotted using coordinates taken on the cultural materials (Figure 1). Unfortunately, the state of many of the cultural materials presently needs urgent and immediate preservative intervention. The structures generally are not in good condition as the traditional buildings need urgent repair or total replacement. In some cases the roofs of these huts are leaking, endangering the contents within. The anthropomorphic structures all around the grove are also in a state of disrepair. Some of them were not completed or have been left deteriorating and are due for a face lift. In certain areas erosion also has come close to eating away the very ground upon which some of these structures stand, as shown in Figure 1. Ironically, one would have thought that with increase in the numbers of visitors and tourists to the grove and its adoption as a World Heritage Site, there would be enough funds carry out regular maintenance. This is not reflected in the condition of many of the cultural artifacts.

\section{Conclusion}

From our rapid survey of the Osun Sacred Grove we recorded a significant amount of biological diversity: 88 plant species, 108 insect families and 4 mammal species. We believe further diversity exists that can be uncovered in an extended sampling of the study area. The pattern of distribution of this biological diversity demonstrates the negative, depleting effect that the buffer and outside zones can have if their encroachment upon the core zone of Osun grove is left unchecked. Insects show decreasing diversity extending outward from the core zone. Also, the small mammals captured in the buffer and outside zones are predominantly commensal species associated with human disturbance. Furthermore, from our water sample analyses, heterotrophic bacteria and fungi were detected at various points in the Osun River (specifically in the core zone of the grove). This indicates the presence of feacal contamination (presumably coming from grazing cattle or indeed human waste in the buffer and outsize zones). This presents a danger to conservation and raises health concerns, as the Osun River within the grove is regularly used for bathing and other religious rituals.

Nevertheless, threats to the environmental sanctity of Osun grove appear to come not only from outside but also within. Access to the grove and the behavior of visitors once inside needs to be monitored more closely. For instance, during our sampling we have observed that the road in Figure 1 which runs right through the grove carries significant daily traffic, with passersby leaving litter and feeding the monkeys unauthorized. With regard to cultural artifacts, the shrines and sculptures should be regularly inspected and maintained, with repairs and restoration work carried out only where absolutely necessary. Overall, ecological and ethnographic balance should be the watchword if Osun Sacred Grove is to remain the exclusive sanctuary of natural and cultural resources we currently know it to be.

\section{Acknowledgements}

The fieldwork was supported by the Centre for Distance Learning, Obafemi Awolowo University. We would also like to acknowledge the assistance of students and all the technical staff in the Natural History Museum, Obafemi Awolowo University, including Adeoba Obadare, Faloba Bakare and Gideon Akinyemi. Kunle Oni helped prepare our digitized map. We thank the staff of the Osun State office of the National Commission for Museums and Monuments for their hospitality and the great lengths they went to facilitate our work.

\section{References}

American Public Health Association (APHA) (1998). Standard Methods for the Examination of Water and Wastewater (20th ed.). Washington DC: American Public Health Association.

Aigbe, H. I., \& Omokhua, G. E. (2015). Tree Species Composition and Diversity in Oban Forest Reserve, Nigeria. Journal of Agricultural Studies, 3, 10-24. http://dx.doi.org/10.5296/jas.v3i1.6461

Ashbolt, H. J., Grahow, W. O. K., \& Snozzi, M. (2001). Indicators of Microbial Water Quality. In L. Fewtrell, \& J. Bartram (Eds.), Water Quality: Guidelines, Standards and Health: Assessment of Risk and Risk Management for Water-Related Infectious Diseases, WHO Water Series (pp. 289-315). London: IWA Publishing.

Ayansola, A., Ige, O. A., \& Adeyemi, C. C. (2003). Mosquitoes Associated with Rock Holes in the Okeiho-Iseyin Area of Southwestern Nigeria. The Nigerian Field, 68, 3-17. 
Babalola, F. D. (2014). Potentials and Challenges of Indigenous Knowledge in conservation of Biodiversity in Osun Osogbo State Sacred Grove, Nigeria. International Journal of Science and Nature, 5, 353-358.

Black, R. (1980) Precambrian of West Africa. Episodes, 4, 3-8.

Baraiah, K. T., Vasudewa, R., Bhagwat, S. A., \& Kushadappa, C. G. (2003). Do Informal Managed Sacred Groves Have Higher Richness and Regeneration of Medicinal Plants than State-Managed Research Forests? Current Science, 84, 804808.

Butynski, T. M., Kingdon, J., \& Kalina, J. (2013). Mammals of Africa. Volume 2: Primates (pp. 319-322). London: Bloomsbury Publishing.

Caro, T. M., \& O’Doherty, G. (1999). On the Use of Surrogate Species in Conservation Biology. Conservation Biology, 13, 805-814. http://dx.doi.org/10.1046/j.1523-1739.1999.98338.x

Convention on Biological Diversity (2006). Guidelines for the Rapid Ecological Assessment of Biodiversity in Inland Water, Coastal and Marine Areas. CBD Technical Series No 22.

Department for Food, Environment and Rural Affairs (2011).A review of fungi in Drinking Water and its Implications on Human Health. Final Report, Reference: WD 0906.

Elsas, J. D., Semenov, A. V., Costa, R., \& Trevors, J. T. (2011). Survival of Escherichia coli in the Environment: Fundamental and Public Health aspects. ISMEJ, 5, 173-183. http://dx.doi.org/10.1038/ismej.2010.80

Habteselassie, M. Y., Bischoff, M., Applegate, B., Reuhs, B., \& Turco, R. F. (2010).Understanding the Role of Agricultural Practices in the Potential Colonization and Contamination by Escherichia coli in the Rhizospheres of Fresh Produce. Journal of Food Protection, 73, 2001-2009.

Happold, D. C. D. (2013). Mammals of Africa. Volume 3: Rodents, Hares and Rabbits (pp. 27-691). London: Bloomsbury Publishing.

Kretz, R. (1983). Symbols for Rock-Forming Minerals. American Mineralogist, 68, 277-279.

Lejeune, J. T., Besser, T. E., \& Hancock, D. D. (2001). Cattle Water Troughs as Reservoirs of Escherichia coli O157. Applied Environmental of Microbiology, 67, 3053-3057. http://dx.doi.org/10.1128/AEM.67.7.3053-3057.2001

Lyngwi, N. A., \& Joshi, S. R. (2015). ‘Traditional Sacred Groves', an Ethnic Strategy for Conservation of Microbial Diversity. Indian Journal of Traditional Knowledge, 14, 474-480.

Mandarino, J. A. (1999). Fleischer's Glossary of Mineral Species 1999 (8th Ed.). Tucson, AZ: The Mineralogical Record Inc.

Mandarino, J. A., \& Back, M. E. (2004). Fleischer's Glossary of Mineral Species 2004 (9th Ed.). Tucson, AZ: The Mineralogical Record Inc.

McLean, A. C., \& Gribble, C. D. (1990). Geology for Civil Engineers (2nd ed., pp. 1-311). New York: John Wiley \& Sons, Inc.

National Commission of Museums and Monuments (NCMM) (2005). Document Submitted to UNESCO for Enlisting OsunOsogbo Grove as World Heritage Site.

Nigerian Environmental Study/Action Team (NEST) (2016). Nigeria's Threatened Environment: A National Profile. www.nestinteractive.org

Obaje, N. G. (2009). Geology and Mineral Resources of Nigeria. In S. B. Brooklyn, H. J. Neugebauer, B. J. Reitner, \& G. K. S. Graz (Eds.), Lecture Notes in Earth Sciences (pp. 1-221). Berlin: Springer-Verlag. http://dx.doi.org/10.1007/978-3-540-92685-6

Ogunjemite, B. G., \& Olaniyi, O. E. (2012). The Chimpanzees of Oluwa Forest Reserve, Southwest Nigeria. International Journal of Development and Sustainability, 1, 823-833.

Ola, A. B., \& Adewale, Y. Y. (2014). Infrastructural Vandalism in Nigerian Cities: The Case of Osogbo, Osun State. Research on Humanities and Social Sciences, 4, 49-60.

Olajire, A. A., \& Imeokparia, F. E. (2000). A Study of the Water Quality of the Òsun River: Metal Monitoring and Geochemistry. Bulletin of Chemical Society Ethiopia, 14, 1-8. http://dx.doi.org/10.4314/bcse.v14i1.71976

Olayemi, A., \& Akinpelu, A. (2008). Diversity and Distribution of Murid Rodent Populations between Forest and Derived Savanna Sites within South Western Nigeria. Biodiversity and Conservation, 17, 2411-2425. http://dx.doi.org/10.1007/s10531-008-9389-1

Perner, J., Wytrykush, C., Kahmen, A., Buchmann, N., Egerer, S., \& Creutzburg, S. (2005). Effects of Plant Diversity, Plant Productivity and Habitat Parameters on Arthropod Abundance in Montane European Grasslands. Ecography, 28, 429-442. http://dx.doi.org/10.1111/j.0906-7590.2005.04119.x

Riley, E. P. (2010). The Importance of Human-Macaque Folklore for Conservation in Lore Lindu National Park, Sulawesi, Indonesia. Oryx, 44, 235-240. http://dx.doi.org/10.1017/S0030605309990925 
Wenger, S. (1990). The Sacred Groves of Osogbo. Austria: Augustine Merzeder.

Wenninger, E. J., \& Inouye, R. S. (2008). Insect Community Response to Plant Diversity and Productivity in a SagebrushSteppe Ecosystem. Journal of Arid Environments, 72, 24-33. http://dx.doi.org/10.1016/j.jaridenv.2007.04.005

World Health Organization (WHO) (2008). Guidelines for Drinking Water Quality: Incorporating 1st and 2nd Addenda, 1, Recommendations (3rd ed.). Geneva: WHO Press.

Williams, N. M., \& Kremen, C. (2007). Resource Distribution among Habitats Determine Solitary Bee Offspring Production in a Mosaic Landscape. Ecological Applications, 17, 910-921. http://dx.doi.org/10.1890/06-0269

\section{Submit or recommend next manuscript to SCIRP and we will provide best service for you:}

Accepting pre-submission inquiries through Email, Facebook, Linkedin, Twitter, etc A wide selection of journals (inclusive of 9 subjects, more than 200 journals)

Providing a 24-hour high-quality service

User-friendly online submission system

Fair and swift peer-review system

Efficient typesetting and proofreading procedure

Display of the result of downloads and visits, as well as the number of cited articles

Maximum dissemination of your research work

Submit your manuscript at: http://papersubmission.scirp.org/ 